\title{
New validated Reverse Phase Ultra Performance Liquid Chromatography method for drospirenone and estetrol in Active Pharmaceutical Ingredient and tablet form and its stress studies
}

\author{
Rafi Syed*, Rambabu Kantipudi \\ Department of Chemistry, RVR JC College of Engineering, Chowdavaram, Guntur, Andhra Pradesh, India.
}

\section{ARTICLE INFO \\ Received on: 08/07/2021 \\ Accepted on: 15/09/2021 \\ Available online: 03/10/2021}

Key words:

UPLC, Drospirenone,

Estetrol, development, validation.

\begin{abstract}
The UPLC technique we have developed is completely unique and reliable and can quantitatively measure drospirenone and estetrol (E4) simultaneously. The chromatographic column of Luna C18 $(100 \times 2.6 \mathrm{~mm}, 1.6 \mu)$ and isocratic elution, with a buffer $(0.1 \%$ formic acid) and acetonitrile $(30: 70 \mathrm{v} / \mathrm{v})$, using a flow of $1 \mathrm{ml} / \mathrm{minutes}$ at room temperature was used. The process was monitored by ultraviolet detection at $262 \mathrm{~nm}$. A total of 3 minutes was dedicated to using a 3 -minute timer to separate drospirenone and E4. Within the concentration range from 3 to $45 \mu \mathrm{g} / \mathrm{ml}$ of drospirenone and $14.2-213 \mu \mathrm{g} / \mathrm{ml}$ of E4, the analysis was completed in less than 5 minutes. System suitability parameters were studied and the outcomes were within acceptable limits when they were injected with the standard six times. To confirm the safety of the formulated product, a market-bought solution was assayed and it was found to be within specification. With all conditions and the acceptable range allowed, degradation studies were carried out on drospirenone and E4, all of which came back with a purity threshold that was higher than the purity angle. This particular technique was found to be consistent with the guidelines set forth by the International Council on Harmonization.
\end{abstract}

\section{INTRODUCTION}

Progestin (Wiegratz and Kuhl, 2004) medications, like drospirenone, are used in birth control pills to prevent pregnancies and are included in hormone replacement therapy (Langer et al., 2021; Stuenkel et al., 2015) for menopausal women, among other applications (Kuhl, 2005). It is available solely under the brand name Slynd, but it is also available in combination with estrogen (or other hormones) under the brand name Yasmin, as well as many other brands. The medication is administered orally. The following are the most common side effects: acne (Scott et al., 2019), headache, breast tenderness (Salzman et al., 2012), weight gain, and menstrual changes (Atteson and Zaluski, 2019; Catalini and Fedder, 2020). Other less common side effects may include a dangerously high level of potassium and blood clots, to name a few (Han and Jensen, 2015). While progestins, or synthetic progestogen, are biologically

"Corresponding Author

Syed Rafi, Department of Chemistry, RVR JC College of Engineering,

Chowdavaram, Guntur, Andhra Pradesh, India.

E-mail: rafiresearch2@gmail.com active as agonists of the progesterone receptor, drospirenone is a progestin (Nath and Sitruk-Ware, 2009) and acts as such by binding to the progesterone receptor. In addition to the amino corticoid (Kolkhof and Bärfacker, 2017; Kosaka et al., 2010) and antiandrogenic (Gillatt, 2006; Iversen et al., 2001) activity, it also has antimineralocorticoid (Kolkhof and Bärfacker, 2017; Kosaka H et al., 2010) and antiandrogenic (Gillatt, 2006; Iversen et al., 2001) activities. The drospirenone molecule is thought to closely resemble bioidentical progesterone in terms of its antimineralocorticoid activity and lack of undesirable off-target activity (Oelkers, 2000, 2002). Drospirenone is used as a progestogen-only birth control pill on its own, in combination with estrogen, ethinyl estradiol, or estetrol (E4), with or without supplemental folic acid (vitamin B9), and for use in menopausal hormone therapy. For the treatment of moderate acne, premenstrual syndrome (Dickerson et al., 2003), premenstrual dysphoric disorder (Pearlstein, 2016; Reid and Soares, 2018), and dysmenorrheal (Gomathy et al., 2019), a birth control pill with low-dose ethinyl estradiol is also indicated (painful menstruation). Moderate to severe vasomotor symptoms (hot flashes) (Freedman, 2014), vaginal atrophy, and postmenopausal osteoporosis (Maclennan et al., 2004; Torgerson and Bell-Syer, 2001) are appropriate uses of this medication. To help reduce the risk 


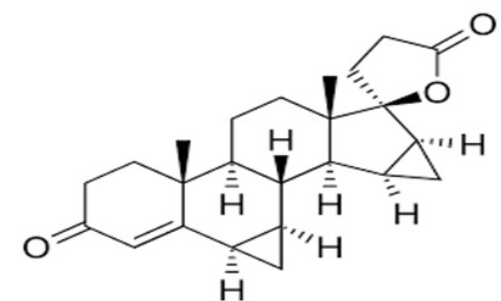

a

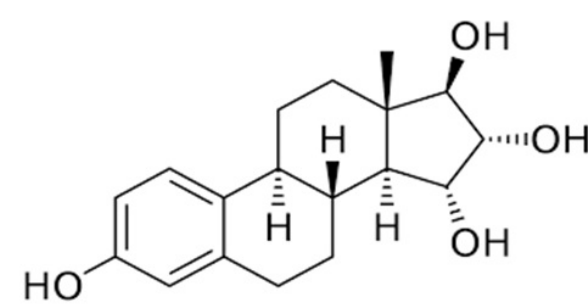

Figure 1. Structural representations of (A) drospirenone and (B) esterol.

of estrogen-induced endometrial hyperplasia (Whitehead, 2006), the drospirenone component has been included in this formulation. Drospirenone has also been used in the treatment of transgender women alongside estrogen as part of hormone therapy (Majumder and Sanyal, 2017; Majumder et al., 2020).

In humans, E4 is present in a detectable amount only during pregnancy (Holinka et al., 2008). Only fetal liver (AbdelMisih and Bloomston, 2010) can make it. E4 is a very similar estrogen to estriol, which is a pregnancy-only hormone that is very prevalent during gestation (Elias and Bengelsdorf, 1952). Estetrol (E4) is a prominent estrogen only during pregnancy. Estetrol is an estrogen and in various tissues it has estrogenic effects. Estetrol interacts with $\mathrm{ER} \alpha$ (which is also known as the nuclear ER) (Levin, 2005) in the same manner as other estrogens, but distinct from that found with SERMs (Abot et al., 2014; Foidart et al., 2019). To date, the physiological role of $\mathrm{E} 4$ has not been determined. Estetrol, a possible fetal wellness marker, has been studied extensively. Pregnancy appeared to be too difficult to control because of the large intra and inter-individual variation in maternal E4 plasma levels (Kundu and Grant, 1976). The chemical structures of drospirenone and E4 are shown in Figure 1.

The present study shows the simultaneous estimation of drospirenone and E4 using UPLC because UPLC allows for better separation and very fast analysis than the HPLC. So, we used the UPLC technique for the separation of drospirenone and E4.

\section{EXPERIMENTAL STUDY}

\section{Chemicals and reagents}

Acetonitrile (99.99\% purity) and formic acid (99.99\% purity) (UPLC marked) were obtained from Merck (India) Ltd, Worli, Mumbai, India. Spectrum Pharma Research Solutions Pvt Ltd, Hyderabad, is the source of the reference standards for drospirenone and E4 APIs.

\section{Equipment}

Waters Acquity UPLC system with a quaternary pump with a PDA detector (PDA lamp) was used. Empower 2.0 was used for data processing.

\section{Chromatographic conditions}

Isocratic chromatography was carried out using a Luna $\mathrm{C} 18$ column $(100 \times 2.6 \mathrm{~mm}, 1.6 \mu)$ at $25^{\circ} \mathrm{C}$ temperature to separate the samples based on their eluent composition. A mixture of 70:30 $v / v$ acetonitrile and $0.1 \%$ formic acid was used as the mobile phase with a flow rate of $1 \mathrm{ml} /$ minute, injection volume of $10 \mu \mathrm{l}$, and total run time of 3 minutes. A chromatographic pressure of 900 psi was maintained in the separation of drospirenone and E4. A wavelength of $262 \mathrm{~nm}$ was selected because the two drugs were absorbed as maximum at the $262 \mathrm{~nm}$ wavelength.

\section{Preparation of buffer}

To make this solution, we dissolved $1 \mathrm{ml}$ of formic acid in a liter of UPLC-grade water and then filter it through a $0.45-\mu$ filter paper (observed $\mathrm{pH}=2.3$ ).

\section{Diluent}

The diluent phase was applied as a moving phase.

\section{Standard preparation}

Carefully we weighed and transferred $30 \mathrm{mg}$ of drospirenone and $142 \mathrm{mg}$ of E4 into a volumetric flask of $100 \mathrm{ml}$ capacity and added approximately $70 \mathrm{ml}$ of diluents, sonicated for 30 minutes to melt it, and then added diluents up to the mark. To make up for the previous solution that was diluted down to $50 \mathrm{ml}$, we diluted the above solution to a total of $5 \mathrm{ml}$ with diluents.

\section{Sample preparation}

Approximately $30 \mathrm{mg}$ of drospirenone and $142 \mathrm{mg}$ of E4 sample were weighed and transferred into a flask of $100 \mathrm{ml}$ with $70 \mathrm{ml}$ of the diluent, which was diluted to the mark with a solution containing diluents. To do this, we took $5 \mathrm{ml}$ of the solution and diluted it to $50 \mathrm{ml}$. We used a $0.45 \mu$ nylon spin-pure disposable syringe filter to obtain a clean, filtered solution.

\section{Method validation}

\section{System suitability}

System suitability parameters were measured in order to confirm system performance. Within acceptable limits, the calculated values for the other two parameters (USP plate count, USP tailing, and RSD percent) were discovered. All the data were obtained from the chromatographic software Empower 2.0.

\section{Specificity}

The capacity to evaluate the analyte unambiguously in the presence of other constituents, while considering the fact that samples and standards are commonly found in the mixture, is 
referred to as specificity. Drospirenone and E4 were used to screen for contamination before the samples were analyzed by UPLC.

Accuracy

Accuracy is the closeness of the test findings to the true value. In vitro and in vivo tests were conducted at three different concentrations in order to assess how well the product works. To meet the minimum requirements, three injections were administered at each level and three different quantities of the drug were used. Afterward, the recovered percentage was calculated alongside the standard deviations for each level.

\section{Precision}

The degree of agreement among multiple independent tests is known as the precision of the analytical technique. The analysis of multiple sampling of homogeneous samples was employed to learn about it. The repeatability, intra-day, and interday variations of the current process were analyzed. Additionally, it was checked by analyzing the samples taken on the same day at various time intervals and on different days.

\section{Linearity}

In linear analytical methods, there is an agreed upon upper and lower limit for the concentrations of the analyte, and any measurement will result in a direct correlation to that level. Six series of standard solutions were selected to examine the linearity range. The calibration curve was plotted and the regression equations were measured using peak area as opposed to the concentration of the standard solution. Using least squares, the slope, intercept, and correlation coefficient were calculated.

\section{Stress degradation}

Under no circumstances should the peaks of the forced degradation solutions used in the chromatogram be interfered with. In accordance with the ICH guidelines, stress degradation studies were conducted. In order to ensure an even degradation across the peaks, the distance between them should be at least 1.0. Only when there is separation will the principle peak purity pass. Forced degradation tests were conducted under various stress conditions (Kulkarni et al., 2016) to evaluate the degradation of approximately $20 \%$.

\section{Robustness}

The robustness of an analytical procedure shows how resilient it is to small differences in the methodology's parameters and indicates how reliable it is in general use. A robustness study was carried out by using the UPLC injection and a range of chromatography settings (flow rate: $\pm 0.2 \mathrm{ml} /$ minute, mobile phase: $10 \%$ organic content, and temperature: $\pm 5^{\circ} \mathrm{C}$ ). The separation factor, retention time, and peak asymmetry were estimated once the effects of the modified parameters were established.

\section{RESULTS AND DISCUSSION}

\section{Method development}

The purpose of this study was to develop a simple, accurate, and rapid RP-UPLC method for simultaneous drospirenone and E4 estimation in bulk and pharmaceutical dosage form. To optimize the chromatographic conditions, different ratios of phosphate buffer and acetonitrile in the mobile phase with isocratic and gradient modes were tested. However, the mobile phase composition was modified at each trial to enhance the resolution and also to achieve acceptable retention times. Finally, $0.1 \%$ formic acid buffer and acetonitrile with isocractic elution was selected because it resulted in a greater response of active pharmacy ingredients. During the optimization of the method, various stationary phases such as C8, C18, and amino, phenyl columns were tested (Kulkarni et al., 2016). From these trials, peak shapes were relatively good with Luna C18 column of $100 \times 2.6 \mathrm{~mm}, 1.6 \mu$, with a PDA detector. The mobile phase flow rate was evaluated at $262 \mathrm{~nm}$ in order to obtain enough sensitivity. The retention time for drospirenone and E4 was 0.989 minutes and 1.878 minutes, respectively. According to the ICH guidelines, all of the proposed methods were validated. The total runtime was 3 minutes. The optimised chromatographic conditions are presented in Table 1.

\section{System suitability}

The system suitability test was completed by injecting six replicates of a standard solution containing $30 \mu \mathrm{g} / \mathrm{ml}$ of drospirenone and $142 \mu \mathrm{g} / \mathrm{ml}$ of E4. These system suitability parameters (Table 2) appeared to be within acceptable limits System suitability chromatogram is shown in Figure 2. All the data were obtained from the chromatographic software Empower 2.0.

Specificity

There was no blanketing of drospirenone and E4 at the retention time of the molecules. In Figure 3, we can see that the chromatogram is empty.

\section{Linearity}

The area of the linearity peak versus different concentrations has been evaluated for drospirenone and E4 as $10 \%, 25 \%, 50 \%, 75 \%, 100 \%, 125 \%$, and $150 \%$, respectively. It

Table 1. Optimized chromatographic conditions.

\begin{tabular}{|c|c|}
\hline Parameter & Proposed method \\
\hline Stationary phase & Luna $\mathrm{C}_{18}(100 \times 2.6 \mathrm{~mm}, 1.6 \mu)$ \\
\hline Mobile phase & $0.1 \%$ formic acid: acetonitrile $(30: 70)$ \\
\hline Injection volume & $10 \mu 1$ \\
\hline Flow rate & $1.0 \mathrm{ml} /$ minutes \\
\hline Column temperature & $25^{\circ} \mathrm{C}$ \\
\hline Wave length & $262 \mathrm{~nm}$ \\
\hline Run time & 3.0 minutes \\
\hline Retention time of drospirenone & 0.989 minutes \\
\hline Retention time of estetrol & 1.878 minutes \\
\hline
\end{tabular}

Table 2. Results of system suitability.

\begin{tabular}{lcc}
\hline Parameter & Drospirenone & Estetrol \\
\hline Theoretical plate count & 2,869 & 5,741 \\
Tailing factor & 1.02 & 0.98 \\
Resolution & - & 4.38 \\
Retention time & 0.989 minutes & 1.878 minutes \\
\hline
\end{tabular}




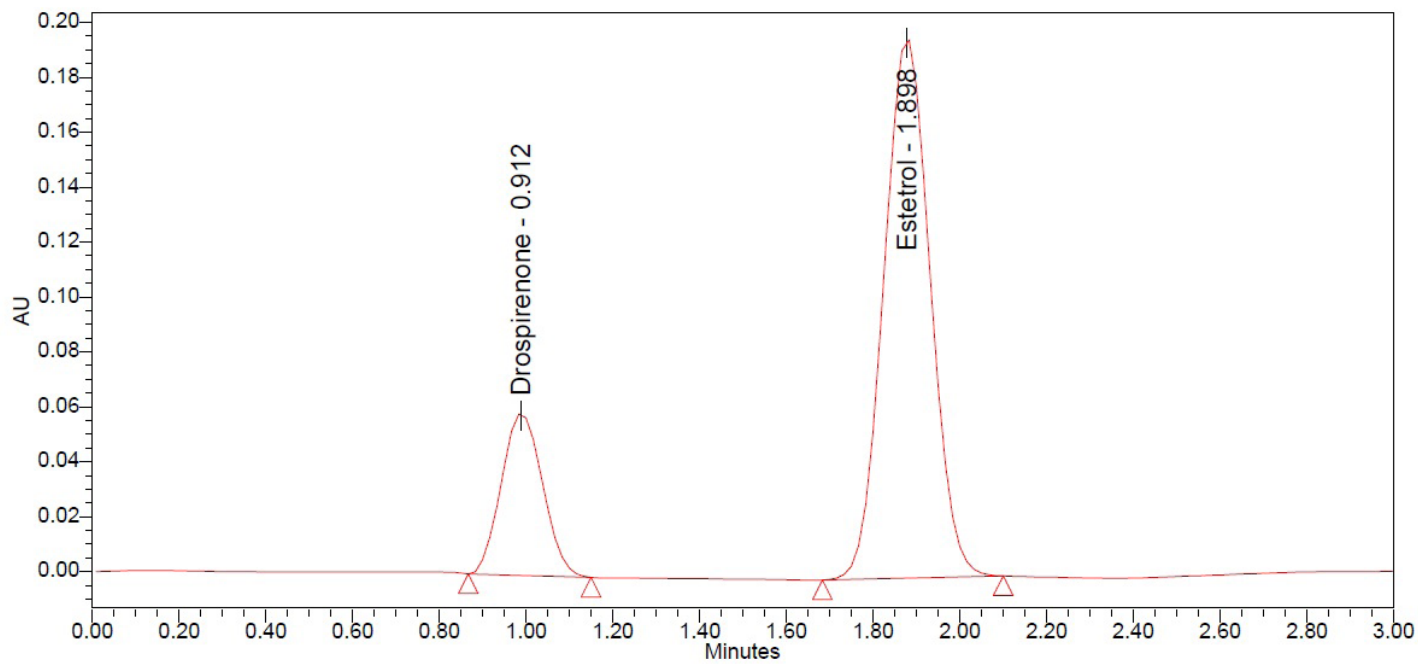

Figure 2. Chromatogram of system suitability.

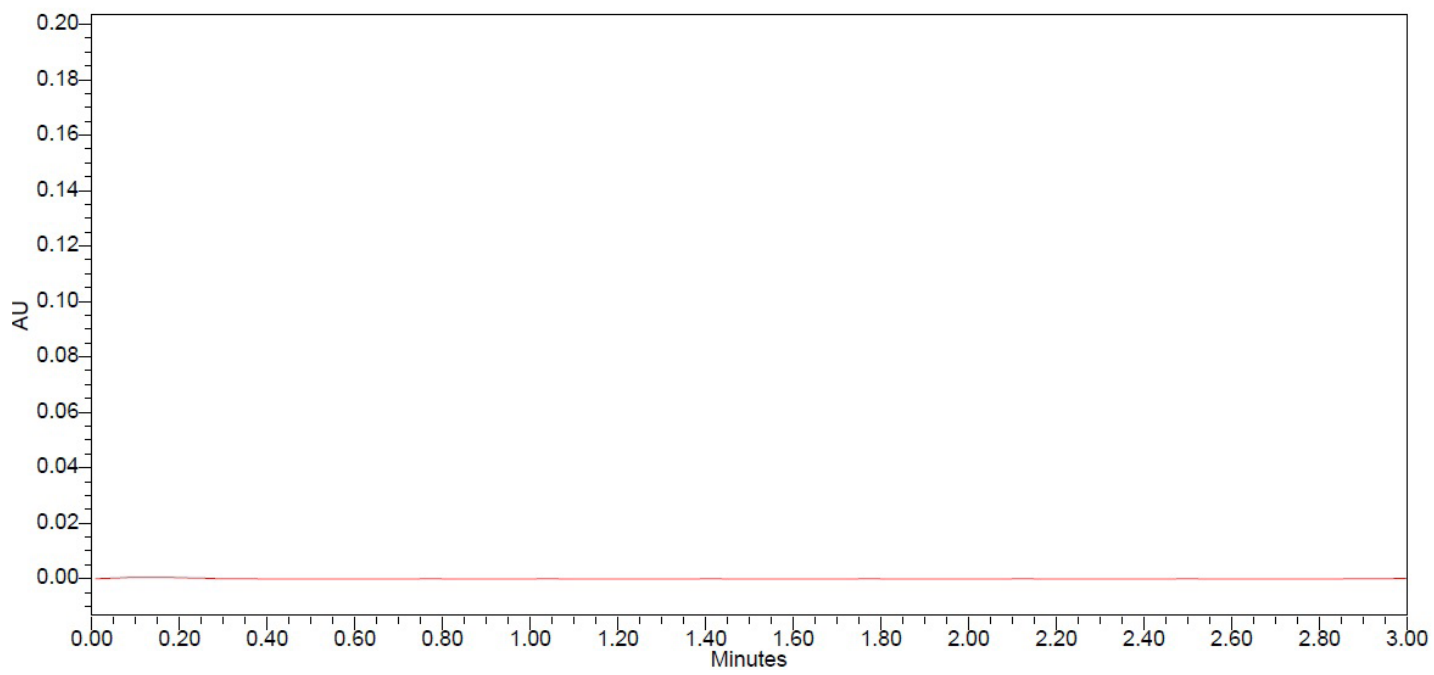

Figure 3. Chromatogram of blank.

was found that the calibration curves were linear between 3.0 and $45.0 \mu \mathrm{g}$ per $\mathrm{ml}(\mu \mathrm{g} / \mathrm{ml})$ for drospirenone and $14.0-213.0 \mu \mathrm{g} / \mathrm{ml}$ for E4. The value of correlation coefficient for drospirenone was 0.9992 and the regression equation was $y=18,252.64 x+87.60$; for $\mathrm{E} 4$, the correlation coefficient was 0.9999 and the regression equation was $y=16,149.69 x+351.33$. The results (Table 3) clearly show the relationship between drospirenone and E4, as demonstrated by the calibration plots (Fig. 4).

\section{Precision}

This method was assessed for intraday and intermediate precision variation accuracy. A sample solution of drospirenone and E4 was examined six times on the same day using six different analytical methods. These analyses were used to find the intraday studies. The research was carried out in the same laboratory by measuring the analytical precision with various analysts and with various analytical instruments. The method
Table 3. Results of linearity.

\begin{tabular}{ccccc}
\hline S. No & \multicolumn{2}{c}{ Drospirenone } & \multicolumn{2}{c}{ Estetrol } \\
\cline { 2 - 5 } & $\begin{array}{c}\text { Concentration } \\
(\boldsymbol{\mu} \mathbf{g} / \mathbf{m l})\end{array}$ & Area & $\begin{array}{c}\text { Concentration } \\
(\boldsymbol{\mu g} / \mathbf{m l})\end{array}$ & Area \\
\hline 1. & 3.00 & 56,014 & 14.20 & 234,633 \\
2. & 7.50 & 129,150 & 35.50 & 564,156 \\
3. & 15.00 & 261,298 & 71.00 & 1132,584 \\
4. & 22.50 & 435,298 & 106.50 & 1726,321 \\
5. & 30.00 & 550,851 & 142.00 & 2326,321 \\
6. & 37.50 & 688,077 & 177.50 & 2862,896 \\
7. & 45.00 & 809,562 & 213.00 & 3424,821 \\
CC & \multicolumn{2}{c}{0.99922} & \multicolumn{2}{c}{0.99992} \\
Slope & \multicolumn{2}{c}{$18,252.64$} & \multicolumn{2}{c}{$16,149.69$} \\
Intercept & \multicolumn{2}{c}{87.60} & \multicolumn{3}{c}{351.33} \\
\hline
\end{tabular}




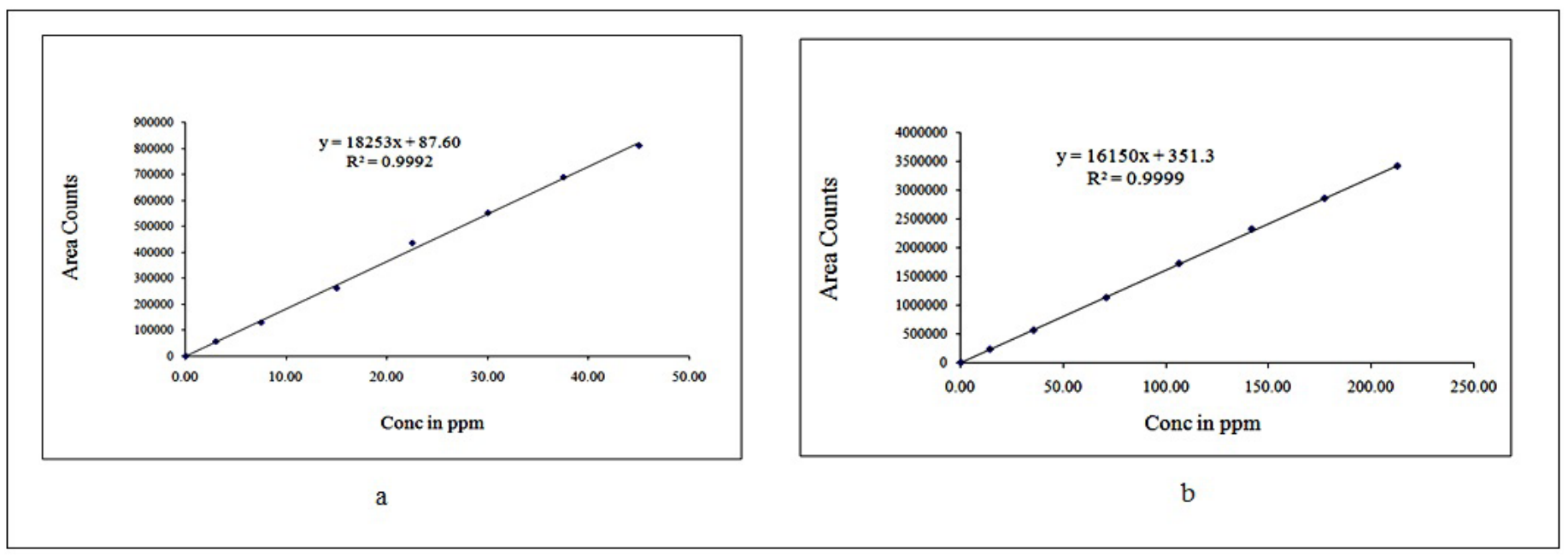

Figure 4. Calibration plots of (a) drospirenone and (b) esterol.

Table 4. Results of method precision.

\begin{tabular}{ccc}
\hline S. No. & Area of drospirenone & Area of estetrol \\
\hline 1. & 562,417 & 2345,012 \\
2. & 501,269 & 2350,234 \\
3. & 542,815 & 2345,025 \\
4. & 546,251 & 2345,873 \\
5. & 536,215 & 2302,125 \\
6. & 524,864 & 2353,641 \\
Mean & 563,972 & 2340,318 \\
Std. dev & $2,101.592$ & $19,024.101$ \\
\% RSD & 0.37 & 0.81 \\
\hline
\end{tabular}

precision results (Table 4) show that the RSD percentage is well under $2 \%$, which allows the methodology to be highly precise. Approximately perfect recoveries of the drug were seen at each added concentration, suggesting that the method was exact.

\section{Intermediate precision (ruggedness)}

Intermediate precision results are shown in Table 5.

\section{Accuracy}

The method's accuracy was confirmed through the recovery experiments at three different levels $(50 \%, 100 \%$, and $150 \%$ ). Drospirenone and E4 APIs were formulated to have 15, 30 , and $45 \mu \mathrm{g} / \mathrm{ml}$ of drospirenone, and 71,142 , and $213 \mu \mathrm{g} / \mathrm{ml}$ of E4, respectively. To simulate an actual application of the test solution, three injections of the test solution were conducted and the assay was executed according to the test method. Over $90 \%$ of the patients achieved full recovery, with RSD values less than or equal to $2 \%$. A percentage recovery calculation was carried out. The values of accuracy (Table 6) were close to what was expected, and the method was effective.

\section{Robustness}

The robustness of the chromatography technique was assessed by varying flow rate, composition of the mobile phase,
Table 5. Results of intermediate precision.

\begin{tabular}{ccccc}
\hline $\begin{array}{c}\text { S. } \\
\text { No. }\end{array}$ & $\begin{array}{c}\text { Area of } \\
\text { drospirenone }\end{array}$ & $\begin{array}{c}\text { Relative standard } \\
\text { deviation }\end{array}$ & $\begin{array}{c}\text { Area of } \\
\text { estetrol }\end{array}$ & $\begin{array}{c}\text { Relative standard } \\
\text { deviation }\end{array}$ \\
\hline 1. & 562,012 & & 2302,568 & \\
2. & 561,365 & & 2345,278 & \\
3. & 567,215 & & 2335,624 & \\
4. & 565,626 & 0.57 & 2335,265 & 0.78 \\
5. & 568,692 & & 2355,869 & \\
6. & 568,576 & & 2343,206 & \\
\hline
\end{tabular}

Table 6. Results of accuracy.

\begin{tabular}{ccccc}
\hline Accuracy & $\begin{array}{c}\text { Amount of } \\
\text { drospirenone }\end{array}$ & $\begin{array}{c}\text { \% } \\
\text { Recovery }\end{array}$ & $\begin{array}{c}\text { Amount of } \\
\text { estetrol }\end{array}$ & \% Recovery \\
\hline $50^{\text {a }}$ & 15 & 99.5 & 71 & 98.8 \\
$100^{\mathrm{a}}$ & 30 & 99.8 & 142 & 99.1 \\
$150^{\mathrm{a}}$ & 45 & 99.9 & 213 & 99.8 \\
\hline
\end{tabular}

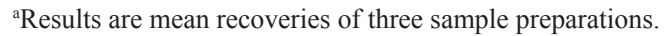

and change in temperature. From the results (Table 7), we found that the percentage of RSD was within the acceptable range.

\section{Forced degradation}

This proposed method is effective for both release and stability studies, and as such, can be seen as a better technique for stability. Acid, base, oxidation, reduction, and thermal degradation are all part of the forced degradation study required by the $\mathrm{ICH}$ requirements. Dependent on the type of chromatography used, it is apparent that the drugs under consideration were stable during the stress testing, even though degraded peaks were observed. Results of forced degradation are presented in Table 8.

Acid degradation: Add $1 \mathrm{ml}$ of the sample stock solution to a volumetric flask of $10 \mathrm{ml}$ and add $1 \mathrm{ml}$ of $1 \mathrm{~N} \mathrm{HCl}$ and leave it for 15 minutes. After 15 minutes, add $1 \mathrm{ml}$ of $1 \mathrm{~N}$ $\mathrm{NaOH}$ and make up to the diluent mark. Filter the solution using a syringe filter and inject it into the UPLC system. 
Table 7. Results of robustness.

\begin{tabular}{lcc}
\hline Parameter & \%RSD of drospirenone & \%RSD of estetrol \\
\hline Flow (0.8 ml/minutes) & 0.55 & 0.29 \\
Flow (1.2 ml/minutes) & 0.82 & 0.89 \\
Organic phase (77:23) & 1.41 & 0.97 \\
Organic phase (63:37) & 0.66 & 0.46 \\
\hline
\end{tabular}

Table 8. Results of forced degradation.

\begin{tabular}{lcc}
\hline \multirow{2}{*}{ Stress parameter } & \multicolumn{2}{c}{ \% of degradation } \\
\cline { 2 - 3 } & Drospirenone & Estetrol \\
\hline Acid degradation $(1 \mathrm{~N} \mathrm{HCl})$ & 14.5 & 14.1 \\
Alkali degradation $(1 \mathrm{~N} \mathrm{NaOH})$ & 14.2 & 13.9 \\
Peroxide degradation $(30 \%$ peroxide $)$ & 15.7 & 14.8 \\
Reduction degradation $(30 \%$ sodium bisulfate) & 13.3 & 12.1 \\
Thermal (sample, $70^{\circ} \mathrm{C}, 6$ hours $)$ & 12.4 & 11.3 \\
\hline
\end{tabular}

Alkali degradation: Add $1 \mathrm{ml}$ of the sample stock solution to a volumetric flask of $10 \mathrm{ml}$ and add $1 \mathrm{ml}$ of $1 \mathrm{~N} \mathrm{NaOH}$ and leave it for 15 minutes. After 15 minutes, add $1 \mathrm{ml}$ of $1 \mathrm{~N} \mathrm{HCl}$ and make up to the mark. Filter the solution using a syringe filter and inject it into the UPLC system.

Peroxide degradation: Add $1 \mathrm{ml}$ of sample stock solution to a volumetric flask of $10 \mathrm{ml}$ and add $1 \mathrm{ml}$ of $30 \%$ hydrogen peroxide solution and make up to the mark with diluents. Filter the solution using a syringe filter and inject it into the UPLC system.

Reduction degradation: Add $1 \mathrm{ml}$ of sample stock solution to a volumetric flask of $10 \mathrm{ml}$ and add $1 \mathrm{ml}$ of $30 \%$ sodium bisulfate solution and make up to the mark with diluents. Filter the solution using a syringe filter and inject it into the UPLC system.

Thermal degradation: The sample solution was set in an oven at $105^{\circ} \mathrm{C}$ for 6 hours. The resultant solution was then injected into the UPLC system.

\section{CONCLUSION}

To quantify drospirenone and E4 in both the API and pharmaceutical dosage form, a novel, rapid, economical, sensitive, and easily available UPLC method was employed. An advantage of this technique is that no UPLC method appears to have been reported. Other merits include low operating costs, quick start-up time, low price, widespread accessibility, pinpoint sensitivity, high reliability, and easily duplicated results. When a larger number of samples must be analyzed, these properties are significant. All the parameters were tested and found to be within acceptable limits. According to the results obtained, the validity of the technique and the results gained are in fair agreement. It would be easy to implement this method for the routine use in quality control laboratories, as well as for the pharmaceutical formulations of drospirenone and $\mathrm{E} 4$, without a preliminary separation step.

\section{ACKNOWLEDGMENTS}

The authors thank Dr. Kantipudi Rambabu (Research guide) and Shree Icon Pharmaceutical Laboratories for all of the support they provided for this research, and they acknowledge their obligation to these two sponsors.

\section{ETHICAL APPROVALS}

This study does not involve experiments on animals or human subjects.

\section{AUTHOR CONTRIBUTIONS}

All authors made substantial contributions to conception and design, acquisition of data, or analysis and interpretation of data; took part in drafting the article or revising it critically for important intellectual content; agreed to submit to the current journal; gave final approval of the version to be published; and agree to be accountable for all aspects of the work. All the authors are eligible to be an author as per the international committee of medical journal editors (ICMJE) requirements/guidelines.

\section{CONFLICT OF INTEREST \\ None.}

\section{REFERENCES}

Abdel-Misih SRZ, Bloomston M. Liver anatomy. Surg Clin North Am, 2010; 90(4):643-53.

Abot A, Fontaine C, Buscato M, Solinhac R, Flouriot G, Fabre A, Drougard A, Rajan S, Laine M, Milon A, Muller I, Henrion D, Adlanmerini M, Valéra MC, Gompel A, Gerard C, Péqueux C, Mestdagt M, RaymondLetron I, Knauf C, Ferriere F, Valet P, Gourdy P, Katzenellenbogen BS, Katzenellenbogen JA, Lenfant F, Greene GL, Foidart JM, Arnal JF. The uterine and vascular actions of Estetrol delineate a distinctive profile of Estrogen receptor $\alpha$ modulation, uncoupling nuclear and membrane activation. EMBO Mol Med, 2014; 6(10):1328-46.

Matteson KA, Zaluski KM. Menstrual health as a part of preventive health care. Obstet Gynecol Clin North Am, 2019; 46(3):441-53.

Catalini L, Fedder J. Characteristics of the endometrium in menstruating species: lessons learned from the animal kingdom. Biol Reprod, 2020; 102(6):1160-9.

Dickerson LM, Mazyck P J, Hunter M H. Premenstrual Syndrome. Am Fam Physician, 2003; 67(8):1743-52.

Elias H, Bengelsdorf H. The Structure of the Liver of Vertebrates. Acta Anat, 1952; 14(4):297-337.

Foidart JM, Jean Michel, Jean Francois Arnal. 30th annual meeting of the north America menopause society september 25-28, 2019, Chicago, IL. Menopause, 2019; 26(12):1445-81.

Freedman RR. Menopausal hot flashes: mechanisms, endocrinology, treatment. J Steroid Biochem Mol Biol, 2014; 142:115-20.

Gillatt D. Antiandrogen treatments in locally advanced prostate cancer: are they all the same?. J Cancer Res Clin Oncol, 2006; 1:S17-26.

Gomathy N, Dhanasekar KR, Trayambak D, Amirtha R. Supportive therapy for dysmenorrhea: time to look beyond mefenamic acid in primary care. J Family Med Prim Care, 2019; 8(11):3487-91.

Han L, Jensen JT. Does the Progestogen used in combined hormonal contraception affect venous thrombosis risk?. Obstet Gynecol Clin North Am, 2015; 42(4):683-98.

Holinka CF, Diczfalusy E, Bennink HJTC. Estetrol: a unique steroid in human pregnancy. J Steroid Biochem Mol Biol, 2008; 110(12):138-43.

Iversen P, Melezinek I, Schmidt A. Nonsteroidal antiandrogens: a therapeutic option for patients with advanced prostate cancer who wish to retain sexual interest and function. BJU Int, 2001; 87(1):47-56.

Kolkhof P, Bärfacker L. 30 years of the mineralocorticoid receptor: Mineralocorticoid receptor antagonists: 60 years of research and development. J Endocrinol, 2017; 234(1):T125-40.

Kosaka H, Hirayama K, Yoda N, Sasaki K, Kitayama T, Kusaka H, Matsubara M. The L, N-, and T-type triple calcium channel blocker benidipine acts as an antagonist of mineralocorticoid receptor, a member of nuclear receptor family. Eur J Pharmacol, 2010; 635(1-3):49-55. 
Kuhl H. Pharmacology of estrogens and progestogens: influence of different routes of administration. Climacteric, 2005; 8(Suppl. 1):3-63.

Kundu N, Grant M, Radioimmunoassay of 15a-hydroxyestriol (estetrol) in pregnancy serum. Steroids, 1976; 27:785-96.

Langer RD, Hodis HN, Lobo RA, Allison MA. Hormone replacement therapy - where are we now?. Climacteric, 2021; 24(1):3-10.

Levin ER. Integration of the extranuclear and nuclear actions of estrogen. Mol Endocrinol, 2005; 19(8):1951-9.

Maclennan A H, Broadbent J L, Lester S, Moore V. Oral oestrogen and combined oestrogen/progestogen therapy versus placebo for hot flushes. Cochrane Database Syst Rev, 2004;2004(4):CD002978.

Majumder A, Chatterjee S, Maji D, Roychaudhuri S, Ghosh S, Selvan C, George B, Kalra P, Maisnam I, Sanyal D. IDEA group consensus statement on medical management of adult gender incongruent individuals seeking gender reaffirmation as female. Indian J Endocrinol Metab, 2020; 24(2):128-35.

Majumder A, Sanyal D. Outcome and preferences in male-tofemale subjects with gender dysphoria: experience from Eastern India. Indian J Endocrinol Metab, 2017; 21(1):21-5.

Nath A, Sitruk-Ware R. Different cardiovascular effects of progestins according to structure and activity. Climacteric, 2009; 12(Suppl1):96-101.

Oelkers W. Antimineralocorticoid activity of a novel oral contraceptive containing drospirenone, a unique progestogen resembling natural progesterone. Eur J Contracept Reprod Health Care, 2002; 7(Suppl3):19-26. discussion 42-3.

Oelkers W. Drospirenone a new progestogen with antimineralocorticoid activity, resembling natural progesterone. Eur J Contracept Reprod Health Care, 2000; 5(Suppl. 3):17-24.

Pearlstein T. Treatment of premenstrual dysphoric disorder: Therapeutic challenges. Expert Rev Clin Pharmacol, 2016; 9(4):493-6.

Kulkarni RM, Bhamare VS, Santhakumari B. Mechanistic and spectroscopic investigations of $\mathrm{Ru}^{+3}$ catalyzed oxidative degradation of azidothymidine by heptavalent manganese at environmentally relavant $\mathrm{pH}$. Desalin Water Treat, 2016; 57(58):28349-62.
Kulkarni RM, Bhamare VS, Santhakumari B. Oxidative transformation of antiretroviral drug zidovudine during water treatment with permanganate: reaction kinetics and pathways. Desalin Water Treat 2016; 57(52):24999-5010.

Reid RL, Soares CN. Premenstrual dysphoric disorder: contemporary diagnosis and management. J Obstet Gynaecol Can, 2018; 40(2):215-23.

Salzman B, Fleegle S, Tully AS. Common breast problems. Am Fam Physician, 2012; 86(4):343-9.

Scott AM, Stehlik P, Clark J, Zhang D, Yang Z, Hoffmann T, Mar $\mathrm{CD}$, Glasziou P. Blue-light therapy for acne vulgaris: a systematic review and meta-analysis. Ann Fam Med, 2019; 17(6):545-53.

Stuenkel CA, Davis SR, Gompel A, Lumsden MA, Murad MH, Pinkerton JV, Santen RJ. Treatment of symptoms of the menopause: an endocrine society clinical practice guideline. J Clin Endocrinol Metab, 2015; 100(11):3975-4011.

Torgerson DJ, Bell-Syer SE. Hormone replacement therapy and prevention of nonvertebral fractures: a meta-analysis of randomized trials. JAMA, 2001; 285(22):2891-7.

Whitehead M. Hormone replacement therapy with estradiol and Drospirenone: an overview of the clinical data. J Br Menopause Soc, 2006; 12(Suppl. 1):4-7.

Wiegratz I, Kuhl H. Progestogen therapies: differences in clinical effects? Trends Endocrinol Metab, 2004; 15(6):277-85.

\section{How to cite this article:}

Syed R, Kantipudi R. New validated Reverse Phase Ultra Performance Liquid Chromatography method for drospirenone and estetrol in Active Pharmaceutical Ingredient and tablet form and its stress studies. J Appl Pharm Sci, 2021; 11(10):106-112. 